\title{
Coconut based integrated farming: A climate-smart model for food security and economic prosperity
}

\author{
B. Sudha*, Jacob John, A.V. Meera, A. Sajeena ${ }^{1}$, D. Jacob ${ }^{1}$ and J.S. Bindhu \\ Integrated Farming System Research Station, Kerala Agricultural University, Karamana, \\ Thiruvananthapuram-695 002, Kerala, India \\ ${ }^{1}$ On Farm Research Centre, AICRP on IFS, Kerala Agricultural University, Vellayani, \\ Thiruvananthapuram-695 522, Kerala, India
}

(Manuscript Received: 16-04-2020, Revised:07-06-2021, Accepted: 30-06-2021)

\begin{abstract}
A coconut-based integrated farming system (IFS) model suited for lowlands was developed at the Integrated Farming System Research Station (IFSRS), Karamana, Kerala state, India, under Kerala Agricultural University. The area of the model was decided as $0.2 \mathrm{ha}$, matching the average per capita land availability of a marginal farmer in the state. Apart from the major crop coconut, intercrops, such as vegetables, fruit crops, spices, fodder and tuber crops were included in the model. The allied enterprises integrated were livestock, azolla, and agroforestry. Tree components of the model comprised of teak, jack, breadfruit, garcinia and mango. Research data for five years revealed that the model generated food products above the requirement of a four-member family, and the surplus production could contribute to farmer's income. The productivity under the IFS model was enhanced tenfolds compared to that under the sole crop of coconut for the same area. Plant nutrients were generated within the farm through organic recycling, which contributed to the substantial saving of chemical fertilizers. The system was found climate-smart because of reduced use of chemical fertilizers and net negative emission of greenhouse gases mostly achieved through agroforestry. This IFS model could also ensure considerable employment generation. The model could be adopted by farmers of lowland tracts of Kerala having similar agro-climatic features for better economic returns and environmental benefits.
\end{abstract}

Keywords: Benefit:cost ratio, carbon sequestration potential, coconut equivalent yield, diversity index, greenhouse gas emission, integrated farming systems, nutrient recycling, sustainability

\section{Introduction}

Coconut has the status of a plantation crop worldwide. Among the main coconut producing states in the country, Kerala ranks first in area and production. Coconut is raised in 7.61 lakh ha and occupies 29.6 per cent of the gross cropped area. However, with respect to productivity, it is fifth, next to Andhra Pradesh, Tamil Nadu, West Bengal and Karnataka (CDB, 2017-18). Unlike several countries where coconut is grown in large gardens, Kerala has a unique feature of coconut-based home gardens that have evolved in response to the pressure of shrinking land resources coupled with high population density. Enhancement of productivity from coconut gardens is extremely important, and a switch to integrated farming becomes increasingly important in this context.

Integrated farming is currently recognized as the most viable strategy in enhancing agricultural production and farm income. Optimum utilization of farm resources through judicious recycling, on-farm generation of organic manures to substitute chemical fertilizers and generation of employment opportunities around the year are the other major benefits of integrated farming. Coconut, the major crop of coastal tracts of India when grown as a monoculture, often leads farmers to distress mainly due to crop loss associated with the pest and disease incidences and market price fluctuations. However, it has been well established that resorting to coconut-based

*Corresponding Author: sudha.b@kau.in 
integrated farming can enhance the yield from the unit area and bring about a considerable hike in farm income, apart from environment-friendly effects resulting from saving fertilizers. The social relevance of such systems also is quite promising, as evidenced by the generation of more employment opportunities.

\section{Materials and methods}

The experiment was carried out at the Integrated Farming System Research Station (IFSRS), functioning under Kerala Agricultural University at Thiruvananthapuram in Kerala, India, a network centre of the All India Co-ordinated Research Project (AICRP) on Integrated Farming Systems, the apex body coordinating research on integrated farming at national level in India. The experimental site was a lowland ( $5 \mathrm{~m}$ above mean sea level) and was located at $8^{\circ} 28^{\prime} 25^{\prime \prime} \mathrm{N}$ Latitude and $76^{\circ} 57^{\prime} 32^{\prime \prime} \mathrm{E}$ Longitude. The soil type was riverine alluvium of sandy clay loam texture.

The station has developed and validated integrated farming models matching Kerala's major crops/cropping situations. A highly successful coconut-based integrated farming system model of 0.2 hectares has been developed by the station, which especially suits the land area and other resources of marginal farmers of the state. The establishment of the IFS model was initiated in the year 2011-12.

Research work carried out for five years suggests that the model is quite successful in generating higher yields, better income, and eco-friendly in terms of on-farm generation of nutrients and providing a negative balance of greenhouse emissions. The various components included in the model are detailed in Table 1.

Coconut trees (West Coast Tall) of 15 years of age, established on bunds raised on the lowland, at a spacing of $7.5 \times 7.5 \mathrm{~m}$, were selected. Water channels of about $2 \mathrm{~m}$ depth were naturally formed between the bunds due to soil excavation from the low lying tract. These channels were utilized in raising fish species viz., Genetically Improved Farm Tilapia (GIFT). Different intercrops comprising of fruit trees (papaya, rose apple), vegetables (vegetable cowpea, ash gourd, amaranthus), spice crops (ginger, turmeric, garcinia, cinnamon), fodder crops (guinea grass, para grass), beverage crops (cocoa), tuber crops (cassava, coleus) etc., were planted in the interspaces of coconut. All along the boundaries of the model, miscellaneous trees were planted, like breadfruit, mango, jack etc. Azolla was raised in two separate pits of $2 \mathrm{~m}^{2}$ each, and it served as fish feed. A dairy unit comprising a cow and a calf was introduced as an integral component of the model. A bee hive that reared stingless honey bees helped in the pollination of vegetables raised in the model. Once the model was well established and yields stabilized by 2014-15, research data were recorded.

On-farm generation of plant nutrients obtained from the byproducts (crop residues, dung, cow's urine, stall wash and nutrient-rich silt from fish pond) were quantified for five years starting from 2014-15. The fertilizer equivalent of plant nutrients generated and the energy equivalent of fertilizers saved was worked out for all these years. The various products from the model were equated as coconut equivalent yield (CEY) and worked out for five years. The economics of the model in terms

Table 1. Coconut based IFS model ( 0.2 ha)

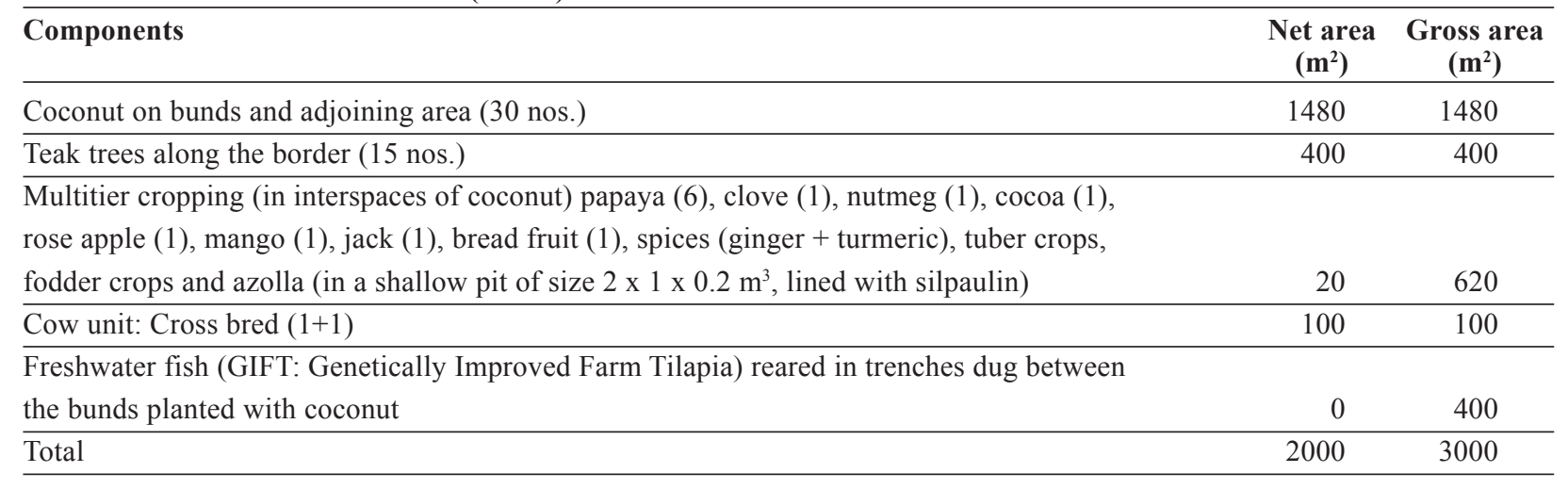


of gross returns, net returns and benefit: cost ratio were also worked out. Greenhouse gas emission is a measure of the carbon sequestration potential of any IFS model, and the net emission of greenhouse gases from the model was worked out for the years 2017-18 and 2018-19 as per the guidelines suggested by the Inter-Governmental Panel on Climate Change. The various sources for the release of greenhouse gas were worked out based on farm activities like the use of inorganic fertilizers, plant protection chemicals, use of energy (operation of farm machinery and consumption of fuel) etc. Activities like crop residue recycling, the addition of organic manures and sequestration of carbon in soil and plant biomass, contributed mostly through agroforestry, were accounted as sinks for greenhouse gases. Carbon sequestered in the soil and plant biomass was estimated as per the life cycle approach suggested by Yadav et al. (2017). Also, the employment generation potential of the system, which is much related to the IFS model's social relevance, was worked out for all these years.

The sustainability yield index (SYI) for each treatment was computed as suggested by Singh et al. (1990).

$\mathrm{SYI}=(\mathrm{A}-\mathrm{SD}) / \mathrm{Ymax}$, where, $\mathrm{A}=$ average yield over the years for a particular treatment, $\mathrm{SD}=$ standard deviation for the treatment and Ymax = maximum yield (average) obtained in any of the treatments over the years. The diversity index was calculated by computing the reciprocal sum of squares of the share of the gross revenue received from each individual farm enterprise in a single year.

\section{Results and discussion}

\section{Nutrient generation from the model}

Data on the generation of major plant nutrients viz., nitrogen, phosphorus and potassium from the coconut-based IFS model in different years under the study are presented in Table 2. The major sources of plant nutrients were crop residues, dairy outputs including cow dung, cow's urine, stall wash etc. Nutrient-rich pond silt, which was excavated from the fish rearing channels in alternate years, was also a source of plant nutrients. The nutrient content of these resources was estimated every year, and the plant nutrient generation was quantified by multiplying the nutrient content by the quantity of each resource produced every year.

On an average, plant nutrients to the tune of $177 \mathrm{~kg}$ nitrogen, $89 \mathrm{~kg}$ phosphorus and $98 \mathrm{~kg}$ potassium were generated annually from the model. These nutrients were recycled into the system itself, thereby saving considerable quantities of chemical fertilizers. The fertilizers equivalent of the nutrients generated is presented in Table 3. Chemical fertilizers to the tune of $386 \mathrm{~kg}$ urea, $446 \mathrm{~kg}$ rock phosphate and $163 \mathrm{~kg}$ muriate of potash could be saved as a result of on farm generation of organic manures. This way, an approximate amount of ₹ 8236/- could be saved annually on fertilizers. Such a considerable saving of fertilizers is definite to impact the environment positively. Several researchers have pointed out the need to shift from fertilizer intensive nutrient management to an integrated nutrient management strategy. Ghosh (2004) opined that intensive use of fertilizers could certainly damage soil quality in the long run. A judicious blend of chemical fertilizers with organic manures is always the right option for plant nutrition. One of the harmful effects of chemical fertilizers, as pointed out by Chandini Kumar et al. (2019), include the release of toxins during the manufacturing process, which can cause air pollution. When the wastes of chemical fertilizers are disposed of untreated in nearby water bodies, it can cause more harmful effects such as water pollution. In these ways, fertilizers as crop production input are depleting our environment and ecosystem. Any reduction of chemical fertilizers in crop production by resorting to integrated nutrient management is always appreciable.

Table 2. On-farm generation of major plant nutrients from the 0.2 ha model $(\mathrm{kg})$

\begin{tabular}{|c|c|c|c|c|c|c|}
\hline \multirow[t]{2}{*}{ Nutrients (kg) } & \multicolumn{5}{|c|}{ Period under study } & \multirow[b]{2}{*}{ Average } \\
\hline & 2014-15 & 2015-16 & 2016-17 & 2017-18 & 2018-19 & \\
\hline Nitrogen & 173 & 127 & 199 & 222 & 166 & 177 \\
\hline Phosphorus & 68 & 69 & 105 & 117 & 87 & 89 \\
\hline Potassium & 71 & 76 & 113 & 125 & 103 & 98 \\
\hline
\end{tabular}


Table 3. Fertilizer equivalent of nutrients generated; price and energy equivalent of fertilizers saved

\begin{tabular}{lccccc}
\hline Year & \multicolumn{3}{c}{ Fertilizers (kg) } & Muriate & \multicolumn{2}{c}{$\begin{array}{c}\text { Energy equivalent } \\
\text { of fertilizers saved } \\
\text { (mega joules) }\end{array}$} & $\begin{array}{c}\text { Price equivalent } \\
\text { of fertilizer } \\
\text { (₹ ) }\end{array}$ \\
\hline $2014-15$ & 376 & 340 & 119 & 12034 & 6721 \\
$2015-16$ & 276 & 345 & 127 & 8971 & 6244 \\
$2016-17$ & 432 & 525 & 189 & 13973 & 9522 \\
$2017-18$ & 482 & 585 & 209 & 16152 & 10594 \\
$2018-19$ & 360 & 435 & 172 & 11735 & 8097 \\
\hline Average & 386 & 446 & 163 & 12573 & 8236 \\
\hline
\end{tabular}

The energy equivalent of fertilizers saved was worked out for individual years, and the average value arrived is presented in Table 3. On an average, 12573 Mega Joules of energy could be saved every year by saving fertilizers. Reports suggest that fertilizer manufacture is an energy-intensive industry. It has been estimated that fertilizer production accounts for approximately 1.2 per cent of the world's energy, of which about 93 per cent is consumed by nitrogenbased fertilizers (Yuan, 2014). To optimize energy inputs and to reduce greenhouse gas emissions from agricultural fields, a reduction in the quantity of chemical fertilizers is much essential (Woods et al., 2010). This can be attained by the on-farm generation of plant nutrients through organic recycling, thereby reducing the purchase of chemical fertilizers. In this context, saving fertilizers, thereby bringing down the energy expenditure on the same, as successfully achieved in this coconut-based integrated farming system model, is of considerable significance in environmental benefits.

\section{Carbon sequestration potential of the IFS model}

The net emission of greenhouse gases from any farming system model is a good indicator of the carbon sequestration potential of the model. Greenhouse gas emission from the model was worked out for two consecutive years viz., 2017-18 and 2018-19 and the data is presented in Table 4. The net negative emission of greenhouse gases could be well related to the farming activities and component selection followed in the model. The model can be rated as climate-smart. Crop residues and dung and urine obtained from livestock components could generate considerable quantities of plant nutrients, thereby reducing the quantity of chemical fertilizers. The animal component was the major source for greenhouse gas emissions, contributing 91 and 79 per cent during 2017-18 and 2018-19, respectively. The role of livestock in GHG emission is noticed through the release of methane and nitrous oxide (Moran and Wall, 2011; Grossi et al., 2019)

The inclusion of tree components in the system, like teak, mango, jack, garcinia, rose apple, breadfruit etc., along with the main crop coconut (Table 1), contributed to the buildup of above and below-ground plant biomass, which could sequester much carbon. Agroforestry/ tree component contributed over 90 per cent carbon sequestration

Table 4. Greenhouse gas emissions from the IFS model

\begin{tabular}{llrr}
\hline $\begin{array}{l}\text { Carbon emissions/ } \\
\text { sequestration }\end{array}$ & Components & \multicolumn{2}{c}{ Period } \\
\hline Source & & $\frac{2017-18}{\mathrm{~kg} \mathrm{CO} \text { equivalent }}$ & $2018-19$ \\
& & 141 & 462 \\
\cline { 2 - 4 } & Crop (cropping systems/ horticultural crops / fodder) & 1451 & 1747 \\
\hline Sink & Animals (livestock/ poultry/ fish) & 1592 & 2209 \\
\cline { 2 - 4 } & Total & 18313 & 18394 \\
& Agroforestry & 1576 & 1249 \\
\hline & Biomass / compost incorporated & 19889 & 19643 \\
\hline & Total & -18297 & -17434 \\
\hline
\end{tabular}


during both the years - 18313 and $18394 \mathrm{~kg} \mathrm{CO}$ equivalent in 2017-18 and 2018-19, respectively. This justifies the negative value for greenhouse gas emission from the model. Trees belonging to Tectonia (Teak) species have very higher carbon sequestration potential and thereby offer much to ecosystem services (Pichhode and Nikhil, 2017). The inclusion of 15 teak trees in this IFS model as boundary planting justifies the higher $\mathrm{C}$ sequestration. Carbon sequestration by trees belonging to 45 species was estimated by Prasadan and Jithila (2018), and they noticed higher sequestration rates with tree species Artocarpus heterophyllus. The IFS model under study included tree components belonging to Artocarpus species viz., A. heterophyllus (breadfruit) and A. integrifolia (jack). This also justifies the net negative emission of greenhouse gases from the model.

More use of nitrogenous fertilizers results in the release of important greenhouse gas nitrous oxide. Integrated farming systems can help mitigate the emission of greenhouse gases through the onfarm generation of manures, thereby reducing the reliance on nitrogenous fertilizers, as reported by Pathak et al. (2014). This observation is in agreement with the present study where on-farm generation of plant nutrients largely saved external purchase of chemical fertilizers.

\section{Yield, economics and employment generation potential of the model}

Data generated on yield and economics of the model are presented in Table 5. From the table, it is inferred that the average value for coconut equivalent yield is 13227 coconuts from an area of 0.2 ha. As the average value for coconut productivity from 0.2 hectares in the state is only 1378 nuts, it is evident that a switch to the integrated farming model can very well enhance production up to even tenfold. This is of very high significance as far as a marginal farmer is concerned. By shifting to an integrated farming approach, the farmer could well enhance production from the limited available land area and could satisfy most of the nutritional demands of the farmer's household. The diverse production from the 0.2 ha IFS model for the period under study is detailed in Table 6. The annual requirement for an average four-member family including four adults under low-cost diet management (Swaminathan, 2010) is presented.

Table 5. Yield, economics and employment generation from the IFS model

\begin{tabular}{lccccc}
\hline Year & $\begin{array}{c}\text { Coconut equivalent yield } \\
\left(\text { nuts 0.2 } \mathbf{~ h a}^{-1} \text { ) }\right.\end{array}$ & $\begin{array}{c}\text { Gross returns } \\
(₹)\end{array}$ & $\begin{array}{c}\text { Net returns } \\
(₹)\end{array}$ & B:C ratio & $\begin{array}{c}\text { Employment generation } \\
\text { (man days per year) }\end{array}$ \\
\hline $2014-15$ & 12213 & 183201 & 52781 & 1.40 & 79.5 \\
$2015-16$ & 10776 & 183191 & 56922 & 1.45 & 69.0 \\
$2016-17$ & 13704 & 232962 & 52595 & 1.28 & 101.0 \\
$2017-18$ & 14274 & 242663 & 69055 & 1.4 & 90.0 \\
$2018-19$ & 15170 & 257891 & 60919 & 1.31 & 87.0 \\
\hline Average & 13227 & 219982 & 58454 & 1.37 & 85.3 \\
\hline
\end{tabular}

Table 6. Diverse food products obtained from the model

\begin{tabular}{|c|c|c|c|c|c|}
\hline \multirow[t]{2}{*}{ Year } & \multicolumn{5}{|c|}{ Food products } \\
\hline & Coconut oil (kg) & Milk (litre) & Fruits (kg) & Vegetables (kg) & Fish (kg) \\
\hline 2014-15 & 137 & 2434 & 105 & 558 & 133 \\
\hline $2015-16$ & 95 & 2884 & 35 & 322 & 81 \\
\hline $2016-17$ & 170 & 2030 & 445 & $1205 *$ & 225 \\
\hline $2017-18$ & 95 & 2884 & 88 & 597 & 155 \\
\hline $2018-19$ & 85 & 3127 & 38 & 756 & 106 \\
\hline Average & 116 & 2672 & 142 & 688 & 140 \\
\hline $\begin{array}{l}\text { Annual requirement for } \\
\text { a four-member family (adults) } \\
\text { under a low-cost diet plan } \\
\text { (Swaminathan, 2010) }\end{array}$ & 66 & 183 & 44 & 429 & 120 \\
\hline
\end{tabular}

*Cassava and ash gourd accounted as vegetables justify the enhanced vegetable production during 2016-17 
Table 7. Sustainability index of the model

\begin{tabular}{|c|c|c|c|c|c|c|c|c|c|c|}
\hline \multirow[t]{2}{*}{ Enterprise } & \multicolumn{5}{|c|}{ Yield data (2014-2019) } & \multirow{2}{*}{$\begin{array}{l}\text { Mean } \\
\text { yield }\end{array}$} & \multirow{2}{*}{$\begin{array}{c}\text { Max. } \\
\text { yield } \\
\text { (Ymax) }\end{array}$} & \multirow{2}{*}{$\begin{array}{l}\text { Standard } \\
\text { Error }\end{array}$} & \multirow{2}{*}{$\begin{array}{l}\text { Standard } \\
\text { Deviation }\end{array}$} & \multirow{2}{*}{$\begin{array}{c}\text { Sustainability } \\
\text { Index }\end{array}$} \\
\hline & $14-15$ & $15-16$ & $16-17$ & $17-18$ & 18-19 & & & & & \\
\hline $\begin{array}{l}\text { Main crop } \\
\text { (Coconut) }\end{array}$ & 2170 & 1583 & 2267 & 1357 & 1133 & 1702.0 & 2267 & 223.07 & 498.80 & 0.531 \\
\hline Intercrops & 663 & 357 & 1650 & 685 & 794 & 829.8 & 1650 & 217.53 & 486.31 & 0.208 \\
\hline Dairy & 2434 & 2884 & 2030 & 2884 & 3127 & 2671.8 & 3127 & 195.67 & 437.53 & 0.715 \\
\hline Fisheries & 2434 & 2884 & 2030 & 2884 & 3127 & 140.0 & 225 & 24.63 & 55.08 & 0.377 \\
\hline
\end{tabular}

The production from the model is higher than the requirement, and surplus food items could be marketed to generate income. The gross returns from the model were estimated to be ₹ $2,19,982$. The average net income from the model was worked out as ₹ 58,454. The benefit: cost ratio of the model was 1.37 and remained higher than 1.0 all these years. This indicates that the model is consistent in generating better profits. The potential of an integrated farming approach in enhancing farm income and contributing to family nutrition, as noticed in the present study, has been reported in many studies. Swarnam et al. (2016) reported that the inclusion of livestock components along with diverse crops in an integrated farming system model of 0.75 hectares could significantly enhance the food diversity and help meet the dietary requirement of a family of five members. Gurjar and Swami (2019) reported integrated farming as the most viable approach for attaining food and nutritional security.

Behera and Mahapatra (1999) reported that IFS could enhance the income of small and marginal farmers of India. In a study conducted in the semiarid tracts of the Telangana region, India, Ramana and Sridevi (2017) reported that, with the adoption of integrated farming (horticultural crops + buffalo + goat), the net farm income enhanced up to ₹ 1.5 lakh per hectare. In contrast, the average income of farmers of the region was only ₹ 54,000 per hectare.

The social relevance of the model in terms of employment generation potential is detailed in Table 5 . On an average, 85 person-days could be generated from the model annually. Khan and Parashari (2018) reported that integrated farming systems offer employment opportunities during off-farm seasons, especially for the care and management of livestock. In a study conducted at Bulandshahr in U.P, employment opportunities and income generation were seen much enhanced for women labourers with the adoption of the IFS approach.

\section{Sustainability and diversity indices of the model}

From the study, the dairy component was identified as the most sustainable $(0.715)$. When combined with other enterprises on scientific lines, the dairy enterprise offers great opportunities for increasing farm income, as reported by Vinodakumar and Desai (2017). The diversity index (value) was worked out for all the years under study. From the second year onwards, there was a considerable enhancement in DI, peaking in the third year of study (3.316), attributed to the enhanced

Table 8. Diversity index of the model

\begin{tabular}{|c|c|c|c|c|c|}
\hline Enterprises & 2014-15 & 2015-16 & 2016-17 & 2017-18 & 2018-19 \\
\hline Main crop (Coconut) & 26030 & 19000 & 34000 & 19000 & 17000 \\
\hline Intercrops & 7741 & 10111 & 34022 & 38731 & 58995 \\
\hline Dairy & 109530 & 129780 & 97440 & 138432 & 150096 \\
\hline Fisheries & 39900 & 24300 & 67500 & 46500 & 31800 \\
\hline Gross returns & 183201 & 183191 & 232962 & 242663 & 257891 \\
\hline Mean & 45800 & 45798 & 58241 & 60666 & 64473 \\
\hline SE & 22240.47 & 28146.69 & 15265.63 & 26560.3497 & 29836.383 \\
\hline SD & 44480.945 & 56293.384 & 30531.278 & 53120.699 & 59672.767 \\
\hline Diversity index & 0.845 & 1.875 & 3.316 & 2.540 & 2.435 \\
\hline
\end{tabular}


income from diverse components of the model. In support of this, Swarnam et al. (2016) reported that the inclusion of different components with diversified species of crops in an integrated farming system could contribute to income generation, thereby improving the value diversity index of the system

\section{Conclusion}

Based on the results, it could be concluded that the components were carefully selected in the coconut-based integrated farming system model and were found complementary. Resource recycling is very well practised within the system. The model is essentially climate-smart because of its less reliance on chemical fertilizers, more carbon sequestration and net negative emission of greenhouse gases. The data suggest that diverse food production contributes to family nutrition, and the surplus could be marketed in generating income. Enhancement of income from diverse components could also contribute to a higher diversity index of the model. The model is consistent in yield performance and is profitable over the years. Lowland farmers of a similar agro-climatic tract could well adopt this model for food security and economic and environmental benefits.

\section{Acknowledgement}

The authors are grateful to the Indian Institute of Farming Systems Research (IIFSR-ICAR) and Kerala Agricultural University for the financial assistance and support for the project.

\section{References}

Behera, U.K. and Mahapatra, I.C. 1999. Income and employment generation of small and marginal farmers through integrated farming systems. Indian Journal of Agronomy 44(3): 431-439.

Chandini Kumar, R., Kumar, R. and Prakash, O. 2019. The impact of chemical fertilizers on our environment and ecosystem. In: Recent Trends in Environmental Sciences (Ed.) Sharma, P., Akinik Publications, New Delhi, India, pp. 69-80.

CDB. 2017-18. Coconut Development Board Statistics 201718 available at https://coconutboard.gov.in/Statistics.aspx

Ghosh, N. 2004. Reducing dependency on chemical fertilizers and its financial implications for farmers in India. Ecological Economics 49(2): 149-162.

Grossi, G., Goglio, P., Vitali, A., and Williams, A.G. 2019. Livestock and climate change: Impact of livestock on climate and mitigation strategies. Animal Frontiers 9(1): 69-76.
Gurjar, G.N. and Swami, S. 2019. Integrated farming systems of valley regions: Food and nutritional security. International Journal of Chemical Studies 7(2): 773-778.

Khan, N. and Parashari, A.K. 2018. Income and employment generation through integrated crop-livestock farming system in Bulandshahr district: A geographical analysis. Acta Scientific Agriculture 2(5): 36-39.

Moran, D. and Wall, E. 2011. Livestock production and greenhouse gas emissions: Defining the problem and specifying solutions. Animal Frontiers 1(1): 19-25.

Pichhode, M and Nikhil, K. 2017. Teak (Tectonia grandis) plantation towards carbon sequestration and climate change mitigation in district Balaghat, Madhya Pradesh, India. International Journal of Innovative Research in Science, Engineering and Technology 6(9): 18674-18685.

Prasadan, P.K. and Jithila, P.J. 2018. Carbon storage and sequestration by trees - A study in Western Ghats, Wayanad region, Indian Journal of Ecology 45(3): 1-5.

Pathak, H., Bhatia, A. and Jain, N. 2014. Greenhouse Gas Emission from Indian Agriculture: Trends, Mitigation and Policy Needs. Indian Agricultural Research Institute, New Delhi, India. p.36.

Ramana, M.V. and Sridevi, S. 2017. Integrated farming system for improving the productivity of smallholder farms in SAT region. In: Proceedings of the Third International Conference on Bioresource and Stress Management (Ed.) Maiti, R. Visva Bharati, Jaipur, pp. 58-62.

Singh, R.P., Das, S.K., Rao, U.M.B. and Reddy, M.N. 1990. Towards Sustainable Dryland Agricultural Practices. Central Research Institute for Dryland Agriculture, Hyderabad, India.

Swaminathan, M. 2010. Essentials of Food and Nutrition. Vol.1. Fundamental aspects ( $2^{\text {nd }}$ ed.). The Bangalore printing and publishing Co. Ltd. pp. 561-610.

Swarnam, T. P., Velmurugan, A., Subramani, T. and Kundu, M.S. 2016. Agrobiodiversity management in integrated farming system for food and nutritional security. International Journal of Plant Research 29: 9-13.

Vinodakumar, S.N. and Desai, B.K. 2017. Dairy based farming system models for livelihood security of small and marginal farmers of North East Karnataka. International Journal of Chemical Studies 5(3): 805-808.

Woods, J. Williams, A., Hughes, J.K., Black, M. and Murphy, R. 2010. Energy and the food system. Philosophical Transactions of the Royal Society B: Biological Sciences 365(1554): 2991-3006.

Yadav, R.P., Bisht, J.K. and Bhatt, J.C. 2017. Biomass, carbon stock under different production systems in the mid hills of Indian Himalaya. Tropical Ecology 58(1):15-21.

Yuan, M. 2014. Managing energy in fertilizer production and use. Report submitted to Stanford University, California, USA. 